Instructions for authors, subscriptions and further details:

\title{
http://mcs.hipatiapress.com
}

\section{List of Reviewers}

Date of publication: February $21^{\text {th }}, 2018$

Edition period: February 2018-June 2018

To cite this article: MCS Editor (2018). List of Reviewers. Masculinities and Social Change, 7(1), 109. doi: 10.4471/MCS.2018.3282

To link this article: http://dx.doi.org/10.447/MCS.2018.3282

\section{PLEASE SCROLL DOWN FOR ARTICLE}

The terms and conditions of use are related to the Open Journal System and to Creative Commons Attribution License (CC-BY). 
MSC-Masculinities and Social Change Vol. 7 No. 1 February 2018 pp.109

\section{List of Reviewers}

I would like to thank all the scholars who served as reviewers in 2017. As the editor of the journal Masculinities and Social Change I am very grateful for the evaluations realized which have contributed to the quality of this journal.

Oriol Ríos

Editor
Álvarez, Pilar
Morlà, Teresa
Gairal, Regina
Ionescu, Vladia
Gelfer, Joseph
Villarejo, Beatriz
Mara, Liviu
Moreno, Sergio
Castro, Marcos
Bento, Paulo
Díez-Palomar, Javier
Albelda, Joan
Ramis, Maria del Mar
Burgués, Ana
Redondo, Gisela
Branz, Juan
Figueroa Perea, Juan G. López de Aguileta, Garazi
Herrero, Carlos
Racionero, Sandra
Serrano, Maria Ángeles
Macías, Fernando
Valero, Diana
Íñiguez, Tatiana 